\title{
Effects of Privatization of Iranian Listed Corporates on their Functions and Performance
}

Habibollah Taherpour ${ }^{1}$ Assistant Professor, Department of Management, Institute for Management and Planning Studies, Tehran, Iran, (Author Corresponding).

Abdolhamid Modaress ${ }^{2}$ Associate Professor, Department of Management, Faculty of management and Economics, Sharif Industrial University, Tehran, Iran. Reza Alaie Koljahi ${ }^{3}$ Ph. D. Student of Public Policy Making, Institute for Management and Planning Studies, Tehran, Iran.

\begin{abstract}
Development of the private sector, running businesses by private sector enterprises and privatization of state-owned enterprises are a dominant approach in most countries. Ample empirical evidence has strongly supported the effectiveness of this approach. In Iran, 39 state-owned companies, whose market value is about $60 \%$ of the total value of the country's stock market, joined the stock market between 2001 and 2015. There were two major objectives behind this move: improving the performance and functions of business enterprises. This paper attempts to identify and analyze the those factors which help privatization to affect the performance and functions of listed firms in Iran's stock market. Findings indicate that privatization is effective in promoting nominal performance and nominal functions of firms, but it cannot lead to the development of their actual performance and business functions. Besides, findings show that the formation of corporate governance, dominant shareholder's status after privatization, the way management controls the quality, and the way privatization affects performance and functional changes of firms each plays a role.
\end{abstract}

Keywords: Privatization, Performance and Functions of Corporates, Profitability, Investment, Stock Market. 

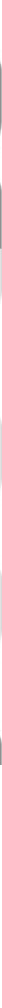

توسعه بخش خصوصى، اداره بنگًامهاى اقتصادى توسط بخش خصوصى، و خصوصى سازى

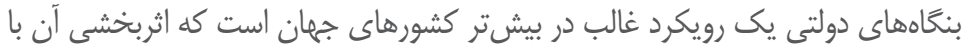

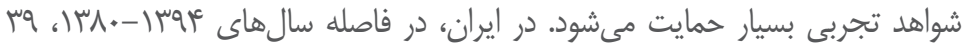

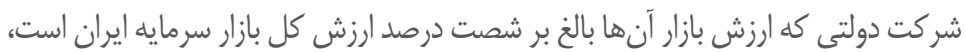

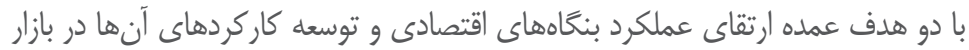

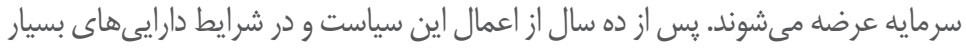

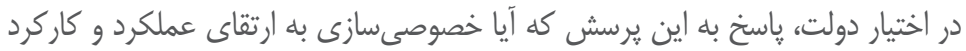

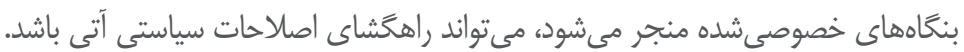

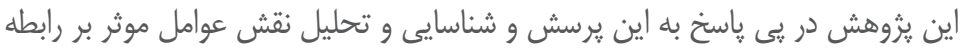

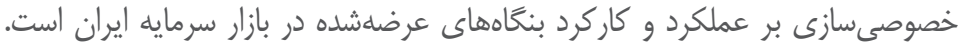

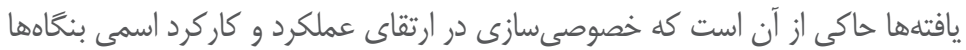

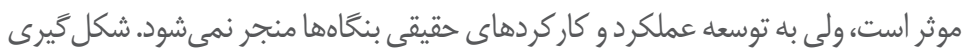

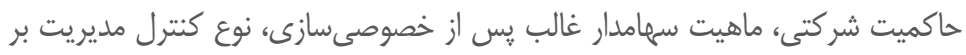

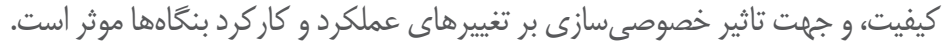

كليلوازهها: خصو صى سازى، عملكرد و كار كرد بنخاهها، سود آورى،

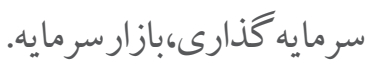

1. استاديار كروهمديريت موسسه عالى آموزش و يُزوهش مديريت و برنامهريزى (نويسنده مسئول). habtaherk@imps.ac.ir

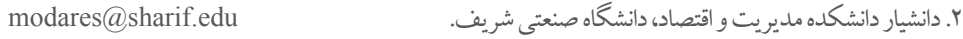
r.alaie@imps.ac.ir

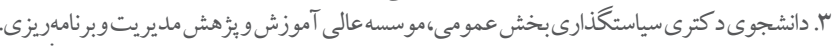




\section{مقامله}

از سالهاى اوليه دهه •191 با اثبات كارايى بالاتر اقتصاد آمريكاى شمالى و ظهور رقباى

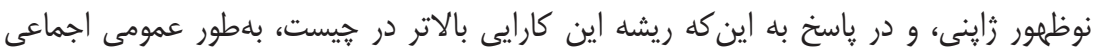

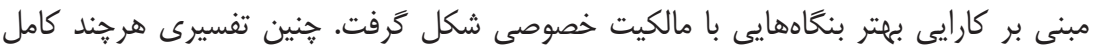

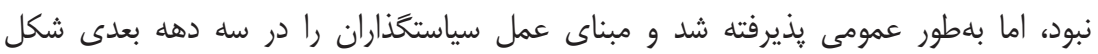

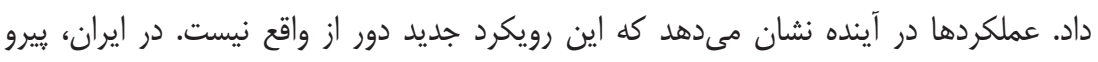
سياستهاى مصوب برنامه سوم توسعه، خصوصىسازى در دستور كار كشور قرار مى گيرد. اما دان يميشزمينههاى لازم براى انجام فرايند كامل خصوصى سازى فراهم نيست، و خصوصى سازى بسيار

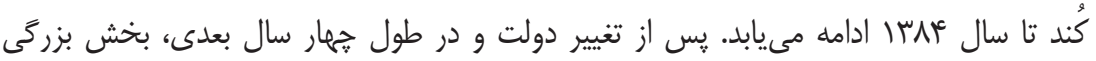

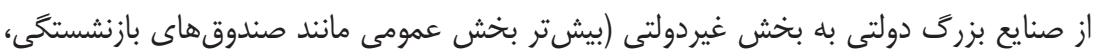

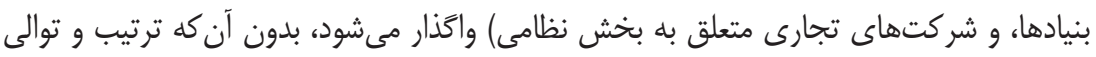

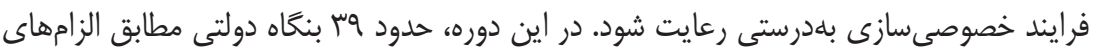

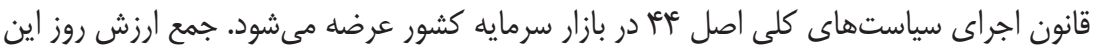

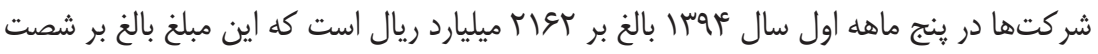
درصد ارزش بازار كل سهام يذيرفتهشده در بازار سرمايه كشور است. با شر كت به صورت مستقيه توسط دولت يا بخش عمومى، و عا شركت توسط شركتهاى متعلق به شركتهاى عرضهشده دولتى به بازار سرمايه عرضه مى شوند.

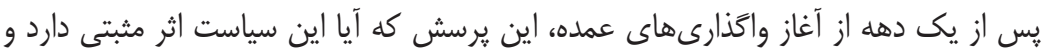

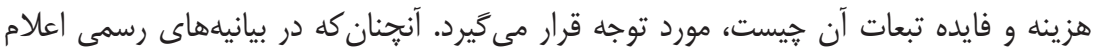

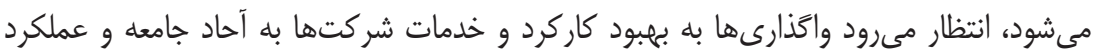
اقتصادى بهتر آنها منجر شود. در اين بيانيهها، ارتقاى سودآورى و سرمايهذَذارى جديد و توسعه

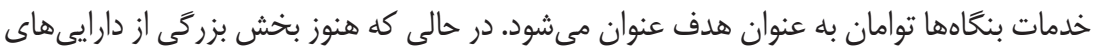

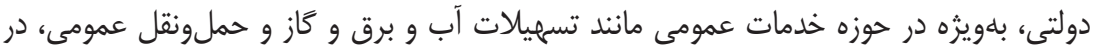

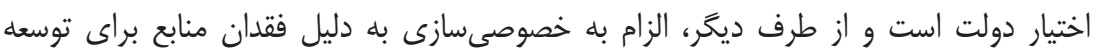
در بخش دولتى و بهاحتمال كارايى بهتر بخش خصوصى در اداره بهتر دارايىها همجنان باقى دئى 
است. اهميت اين ارزيابى و اصلاحات سياستى متعاقب آن در سياست و روشهاى اجرايى ييشين

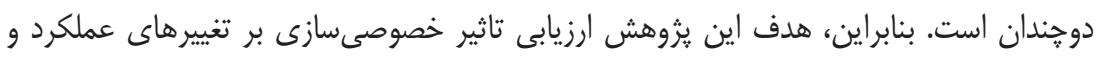
كاركرد شركتهاى خصوصىشده، بررسى نقش عوامل موثر بر كيفيت و جهت اين تاثير، و ارائه خط راهنمايى براى اصلاحات سياستى آتى است.

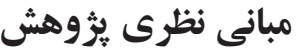

ادبيات موضوع خصوصىسازى آكنده از استدلالهاى له يا عليه منافع خصوصىسازى است. مطالعه شواهد تجربى بين كشورى، سرىهاى زمانى، و مطالعهایى موردى نتايج مختلفى از منافع و زيان ايجادشده نشان مىدهد. در حالى كه سياستهاى خصوصىسازى با اهداف سياستى كوناكونى در كشورهاى مختلف اجرا مىشود، بجاست برسش شود كه آيا اين سياستها مفيد و

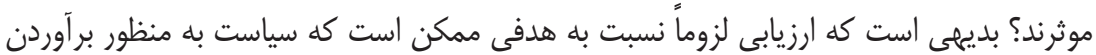

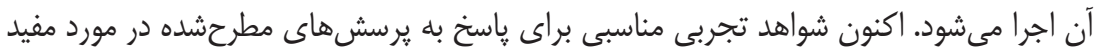

بودن خصوصىسازى وجود دارد.

بخش بزركى از توجيهات برنامههاى خصوصىسازى اشاره مى كند كه اين برنامهها مىتواند

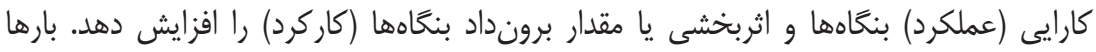
يزوهشكَران حوزهُ سياست اثركذارى عوامل زمينهاى درون و برون بنكاهى را خاطرنشان مى كنند. يس ضرورى است به منظور طراحى بهتر سياست براى اطمينان بيشتر از تحقق اهداف اصلى اشارهده، سازوكار اثركّارى خصوصىسازى بر كاركرد و عملكرد بنگاه با دقت بررسى شود.

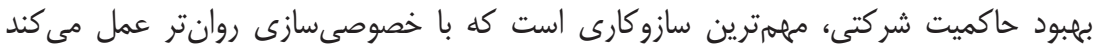
و باعث تقويت آثار مثبت مورد نظر از خصوصىسازى مىشود. بحران آسيايى 1999 و بحران انسان

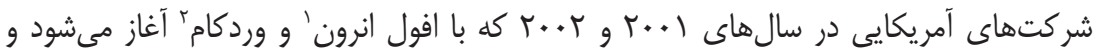

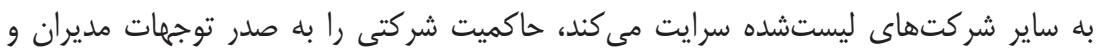
سياستخذاران مى كشاند. فريدمن و همكاران؟ (1999)، در راستاى همين ديدكاه استدلال مى كنتد كه خصوصىسازى بايد به تغيير مديريت و روشهاى اداره بنگاه منجر شود. آنها بيان مى كنند كه تاثير خصوصىسازى بر عملكرد شركتها بهطور غيرمستقيه و از طريق بهتر كردن حاكميت

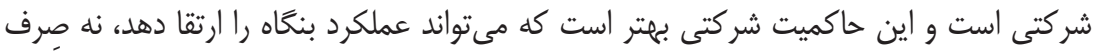

1. Enron

2. Worldcom

3. Frydman et al. 
انتقال مالكيت از بخش دولتى به بخش غيردولتى. خصوصىسازى به غير از بهبود حاكميت

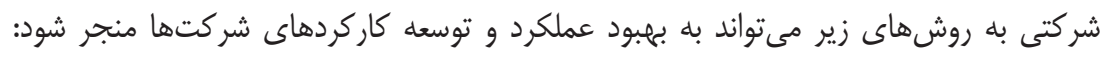

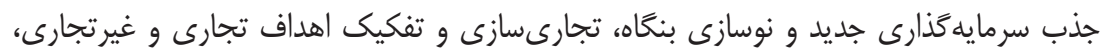

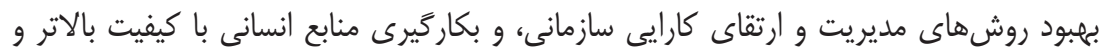
انغيزش موثرتر آنها. نسبت دادن تغييرها در كاركردها و عملكردهاى يك بنغاه در سالهاى قبل و بعد از

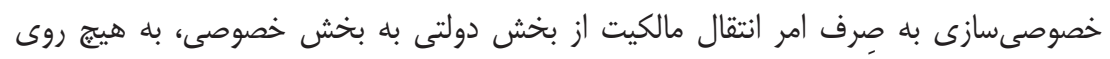

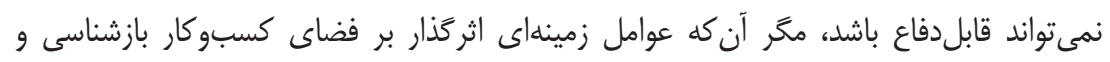

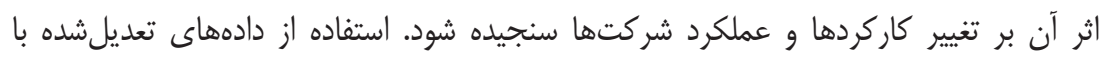

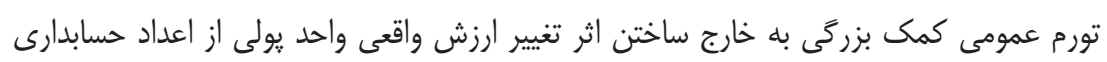

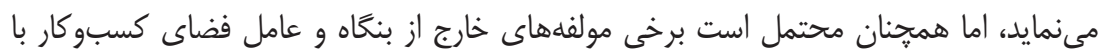

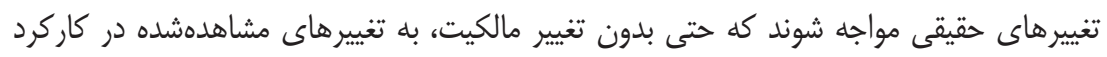

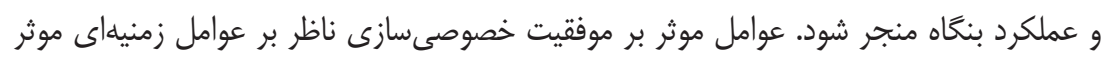

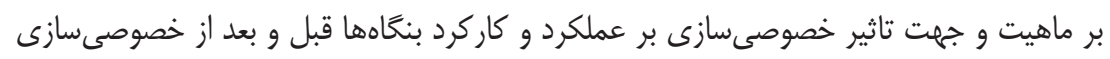

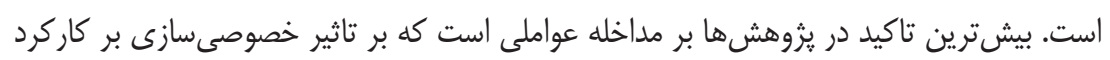

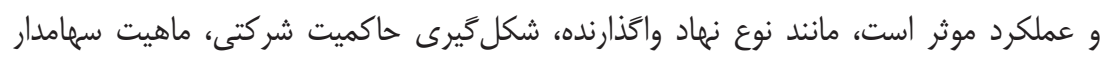

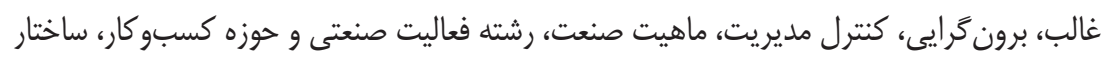

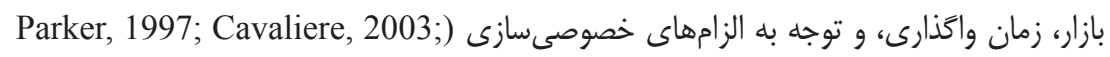
.Frydman et al., 1999; D’souza \& Megginson, 1999; Verbrugge et al., 1998

\section{سنجش كار كرد و عملكرد شر كتها}

توسعه كاركردهاى بنكاه از طريق توسعه سرمايهذارى بهدست مى آيد و سرمايهگذارى

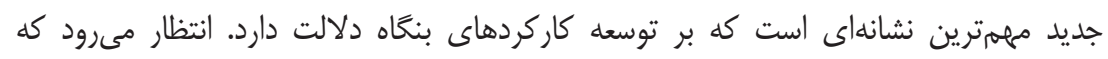

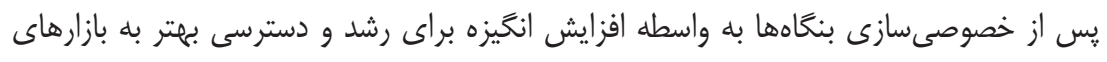

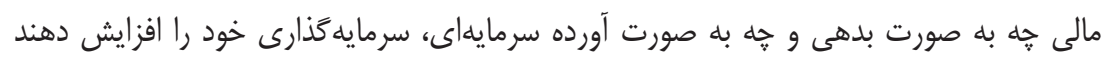

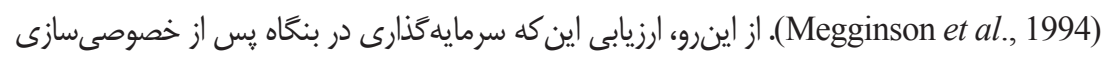
تا קه اندازه رشد دارد، يكى از مهمترين شاخصهاى ارزيابى موفقيت سياست خصوصى الرسازى است.

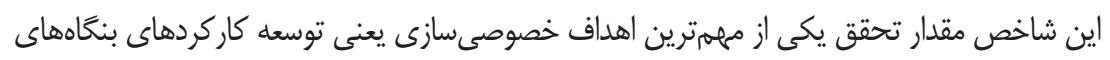


خصوصىشده را ارزيابى مى كند و بهطور همزمان قضاوت روشنى از اثر سياست خصوصىسازى ارائه

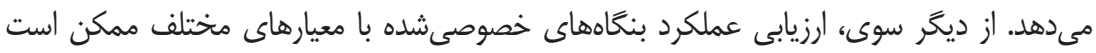
.(Verbrugge et al., 1999; Boubakri \& Cosset, 1998; D’Souza \& Megginson, 1999) آنجه مد نظر اين يثوهش است، ارزيابى تاثير سياست روى متغيرهايى است كه براى سياستخذار اهميت

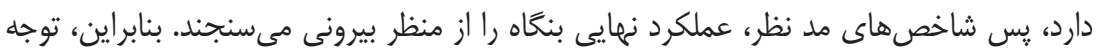
و تمركز روى شاخصهايى مانند مقاير مطلق سود ايجادشده، بازده سرمايه، و بازده داريى هائات

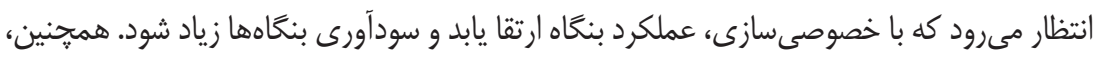

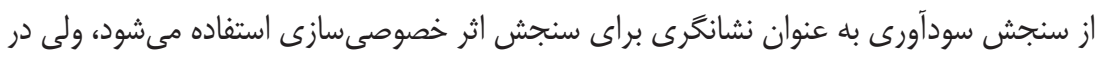

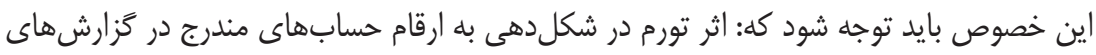

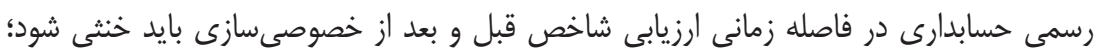

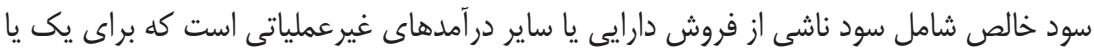

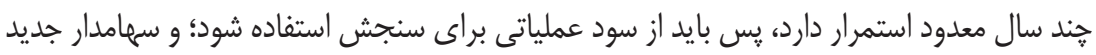
با دستكارى در رويههاى حسابدارى، مايل باشد مقدار واقعى سود را بيشتر يا كمتر نشان دهد.

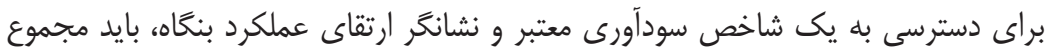

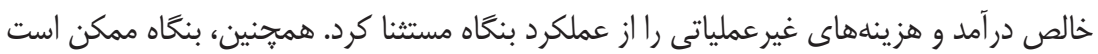

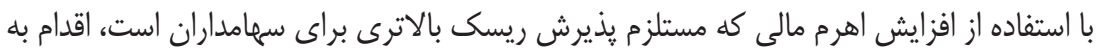
توسعه دارايىها و سود نمايد، پِ مفيد است كه شاخص سنجش عملكرد دوباره با كسر هزينهائهاى

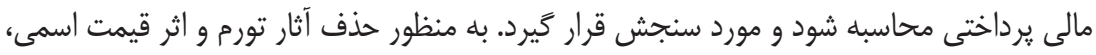

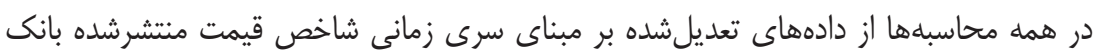

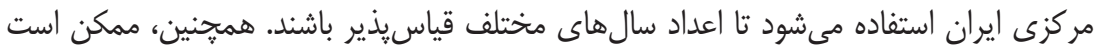

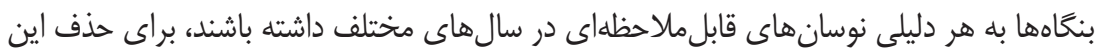
نوسانها، از ميانخين شاخصهاى محاسبهشده براى يك تا سه سال قبل و بعد از خصوصىسازى لـان

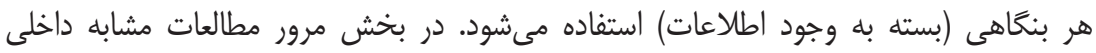
و خارجى، همراه با ساير مشخصات يُوهشهاى صورت كرفته، معيارهاى مورد استفاده ساير يزووششها به تفصيل كزارش مىشودا.

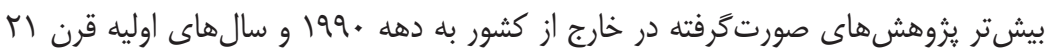

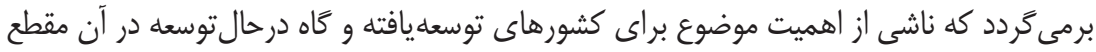

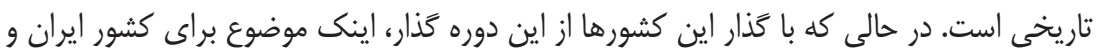


كشورهاى مشابه آن اهميت يافته است. در اين بخش، يزوهشهاى مهمى كه بلطور مستقيم به

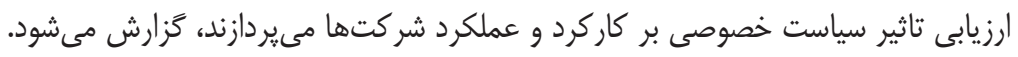

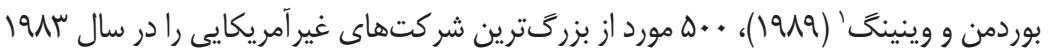

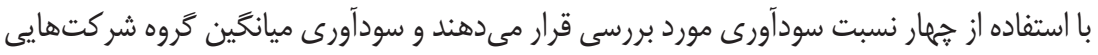

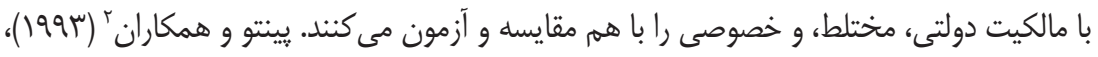

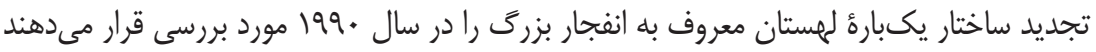

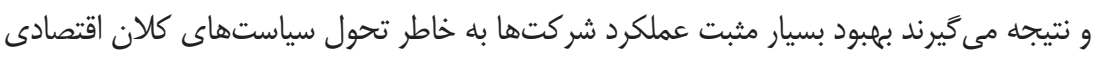

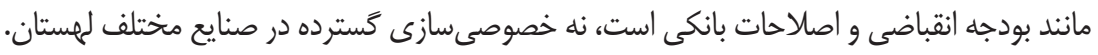

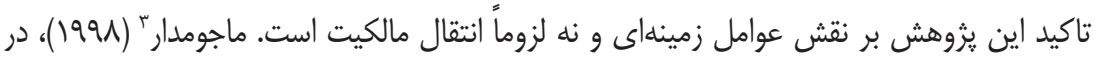

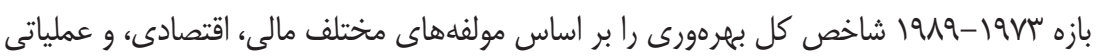
تعريف مى كند و در مورد كروه شركتهايى با مالكيت مختلف در بازار سهام هند نتيجه مى گئيرد

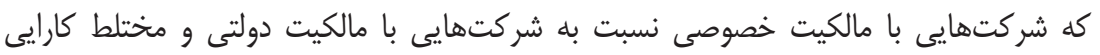

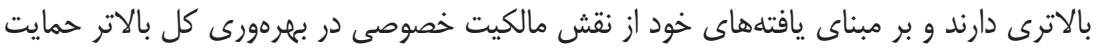

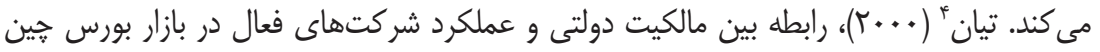

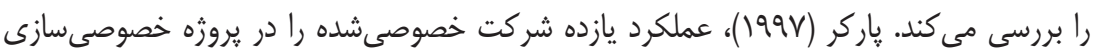

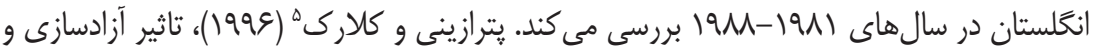
خصوصى سازى را بر كار كرد و عملكرد شركتهاى مخابراتى بررسى مى كنند. مخَينسون و همكاران

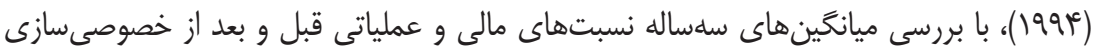

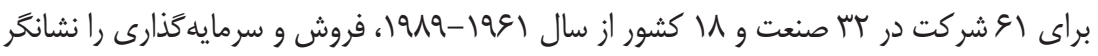

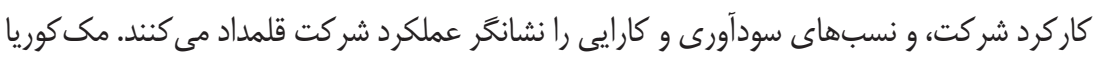
कर

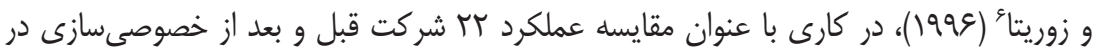

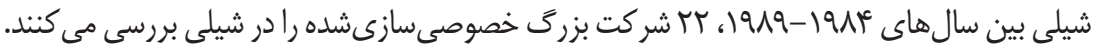
آنها به دليل وجود تورم بالا در شيلى مجبور مىشوند از دادههاى تعديلشده استفاده كنند. وربروى

\section{Boardman \& Vining}

2. Pinto et al.

3. Majumdar

4. Tian

5. Petrazzini \& Clark

6. Macquieira \& Zurita 
و همكاران (1991)، در بانك جهانى مفاد قراردادهاى واگذارى و ساختار مالكيتى، ه9 بانكى را كه از سال 1911 تا 1999 به صورت كامل يا نيمه كامل خصوصى شدهاند، مطالعه مى كنند و عملكرد قبل و بعد از خصوصىسازى זr بانكى را در كشورهاى عضور مقايسه مى كنند. آن ها شاخصهاى سودآورى، درآمد تراكنش به كل درآمد، كفايت سرمايه، و نسبت

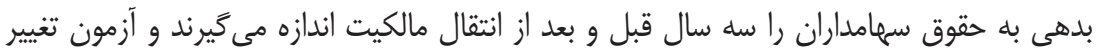

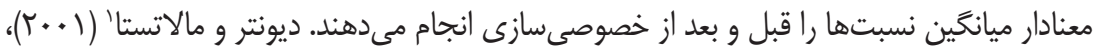

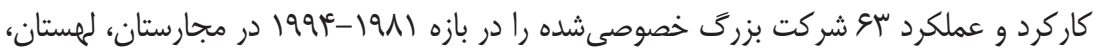
و انغلستان قبل و بعد از خصوصىسازى در كوتاهمدت و بلندمدت بررسى مى كنند و در ادامه براى

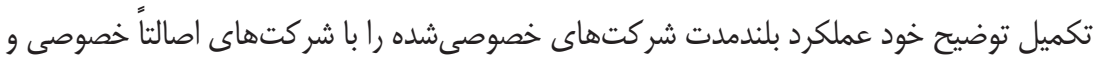
دولتى در بازه 19VD-1919 1990 مورد مقايسه قرار مى دهند. در خصوص ارزيابى سياست خصوصى سازى در ايران، يزوهش هايى كه منتشر مىشود مى تواند

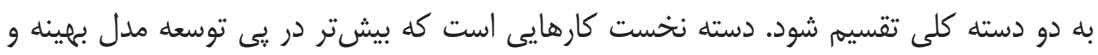

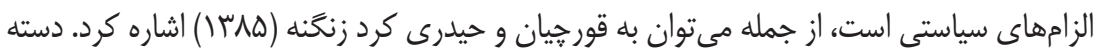

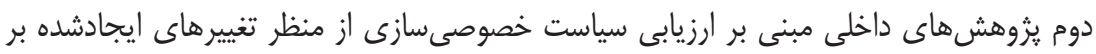

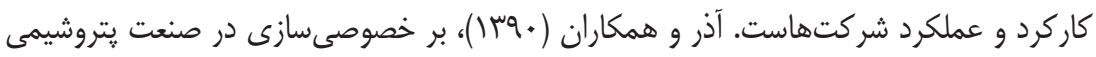

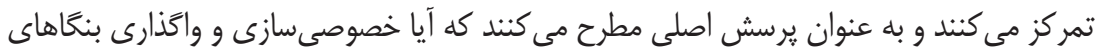

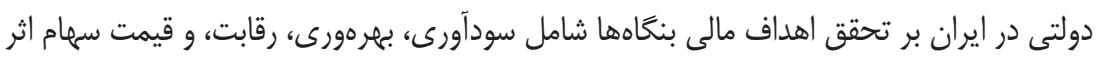

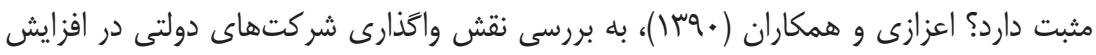

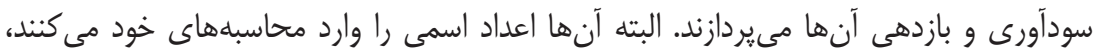

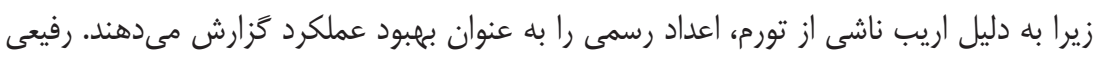

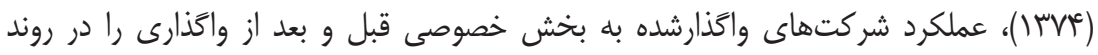

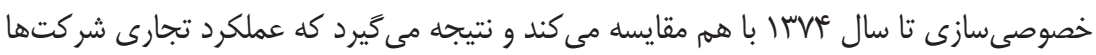

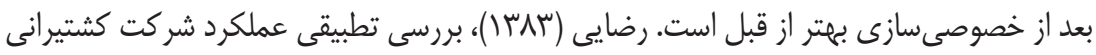

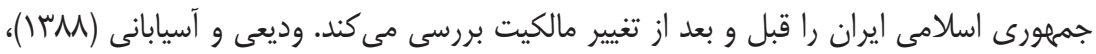

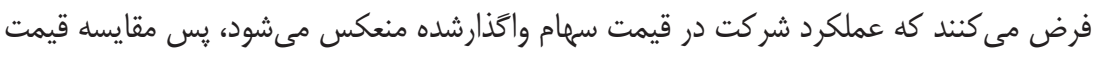

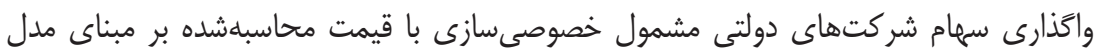

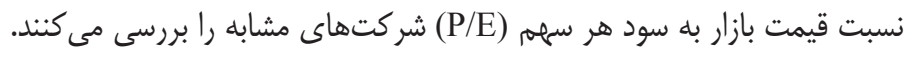

1. Dewenter \& Malatesta 


\section{سياست خصوصىسازى در ايران}

اقتصاد ايران از اوايل دهه •هّرا در مسير دولتىتر شدن است. سند سياستهاى كلى نظام

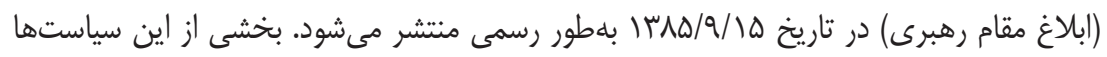

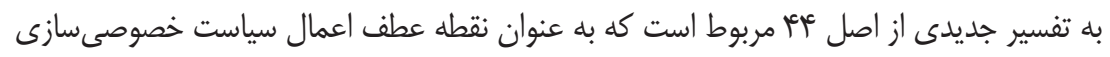

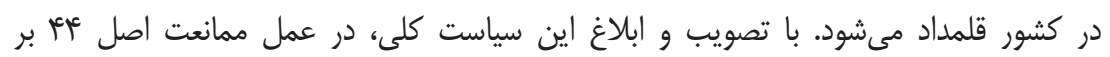

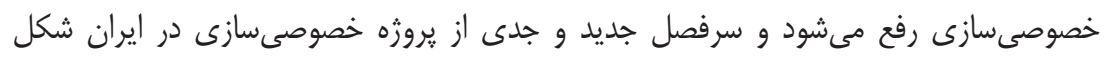

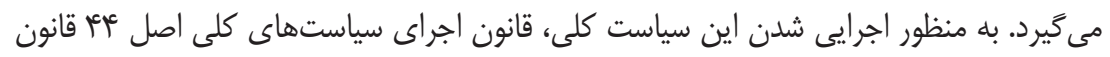

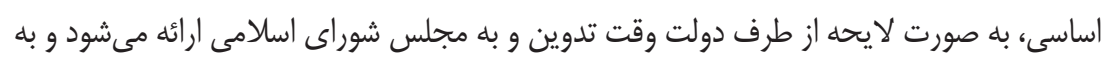

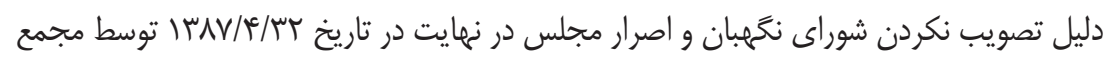

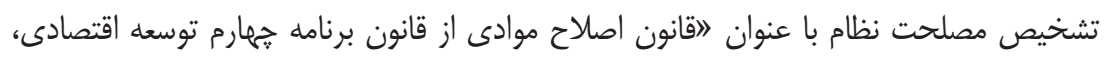

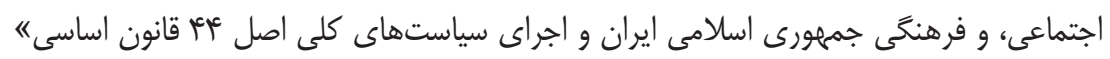

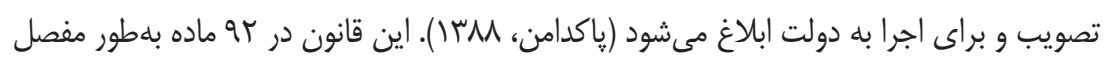
به واگذارى دارايى ها و بنكامهاى دولتى مىيردازد.

\section{عملكرد خصوصىسازى در ايران}

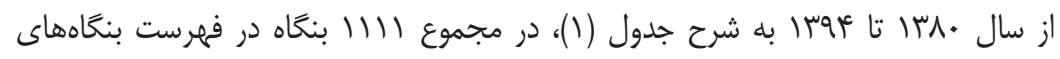

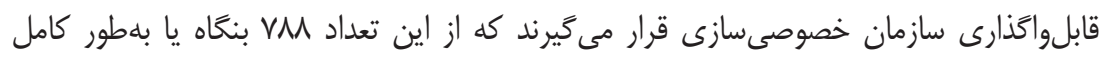

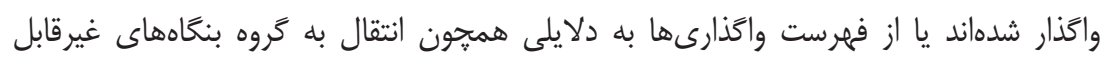

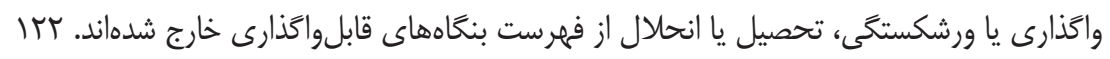

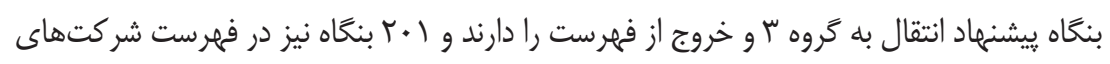

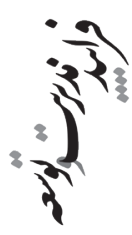
قابلواكذارى سال هاى بعد قرار مى گيرند. 


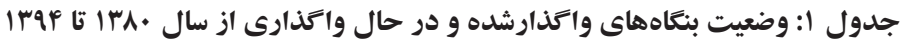

\begin{tabular}{|c|c|c|c|c|c|c|c|c|c|}
\hline \multirow{4}{*}{ كل } & \multirow{4}{*}{ واخذارى هونامه } & \multicolumn{3}{|c|}{ 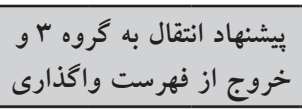 } & \multicolumn{4}{|c|}{ واگذارى و خروج كامل } & \multirow{4}{*}{ عنوان } \\
\hline & & \multirow{3}{*}{ موع } & بيشنهاد & بيشنهاد & & انتقال به & انحلال، & \multirow{3}{*}{ فروش } & \\
\hline & & & خروج از & انتقال به & مجموع & كروه rو & تحصيل، & & \\
\hline & & & فهرست & كروه r & & خروج & ورشكستخى & & \\
\hline GYY & 1.1 & ITr & $9 \pi$ & rq & 419 & ITY & Q. & TYQ & موضوع آييننامه ماده \\
\hline 499 & $1 \cdots$ & - & . & . & r49 & r & $9 V$ & r.. & خارج از آييننامه ماده \\
\hline 1111 & $r \cdot 1$ & IrT & $q \pi$ & rq & VA & ITS & $11 \mathrm{~V}$ & DYO & جمع كل \\
\hline$\% 1 \ldots$ & $\% 1 \wedge$ & $\% 11$ & $\% \wedge$ & $\%$ & $\%$ & $\% 11$ & $\% 11$ & $\%$. & درصد نسبت به كل \\
\hline
\end{tabular}

منبع: تز ارش ساليانه سازمان خصوصىسازى سال IFqF

واگذارىها در سالهاى •رسا تا عوسا به سه نوع واگذارى شامل عرضه و فروش سهام و دارايى به صورت رقابتى به عموم متقاضيان، واگذارى سهام و دارايى بابت رد ديون دولت، و انتقال مستقيم سهام و دارايى به ذىنفعان است. از بيش از عأ|ا هزار ميليارد ريال سهام واكذارشده در اين بازه زمانى حدود الم هزار ميليارد ريال معادل DV/9 درصد واكذارىها به صورت رقابتى

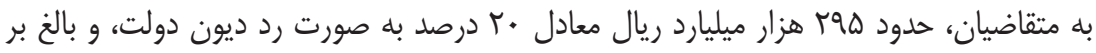

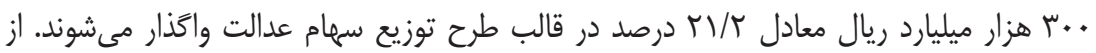
كل ارزش سهام واكذارشده در اين بازه زمانى اع درصد از طريق عرضه در بازار سرمايه (شامل

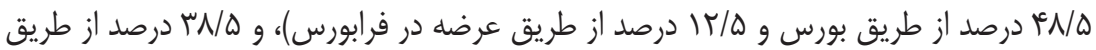
برگزارى مزايدههاى غيربورسى صورت مى گيرد (www.ipo.ir). از جمله ايرادهاى واردشده بر

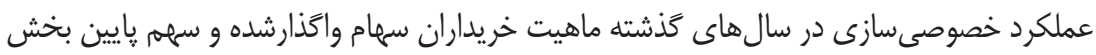
خصوصى واقعى است. اين امر تحقق يكى از مهمترين اهداف خصوصىسازى، مبنى بر ارتقاى

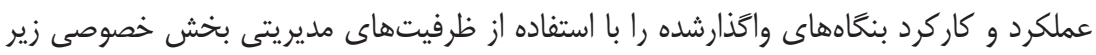
سوال مىبرد. سهم بخش خصوصى واقعى از كل واگذارىها در سالهاى •ریّا تا پايان سال

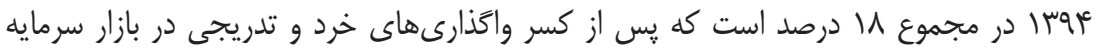
و نيز واكذارىهاى سهام ترجيحى به كمتر از fال درصد مىرسد. در حالى كه بيش از • ب درصد از جمع كل دارايىهاى خصوصىشده به سهام عدالت تعلق دارد، بخش زيادى از تلاش سازمان 
خصوصىسازى نيز معطوف به سازماندهى سهمم عدالت است. اين در حالى است كه سهام عدالت

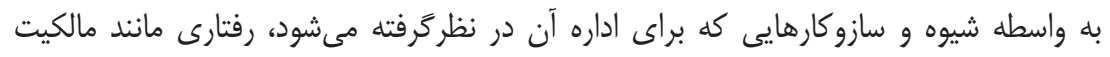

$$
\text { دولتى دارد. }
$$

\section{روش اشناسى ثئوهش}

هدف اين بزوهش، ارزيابى اثرهاى خصوصىسازى بر تغييرهاى عملكرد و كاركرد بنكاههاى

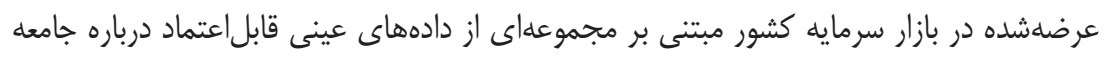

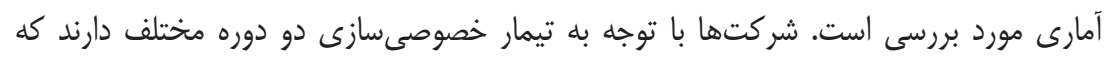

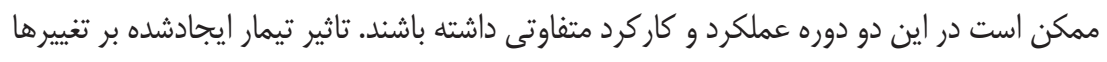

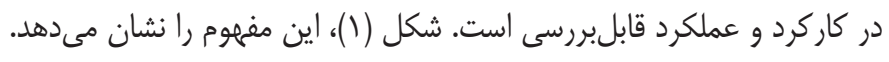
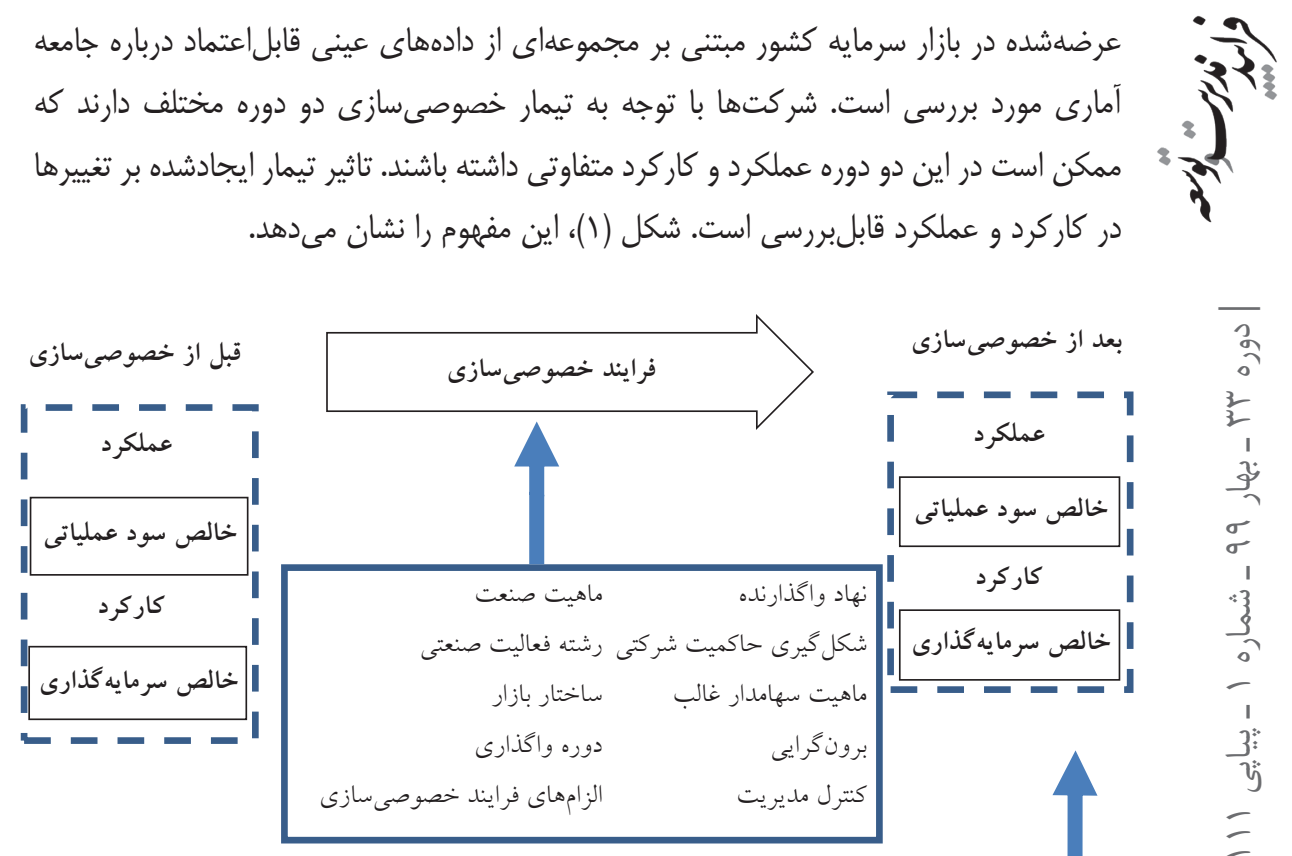

عوامل موثر در تاثير خصوصى سازى بر تغييرهاى عملكرد و كاركرد بنكاهها

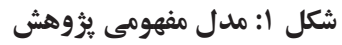

ارزيابى تاثير خصوصىسازى بر عملكرد و كاركرد بنغاههاى عرضهشده در بازار سرمايه ايران

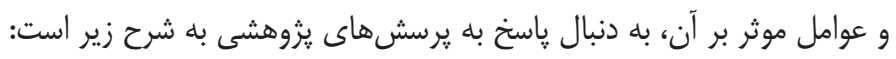

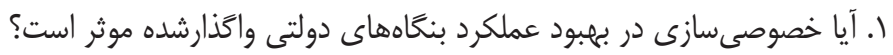

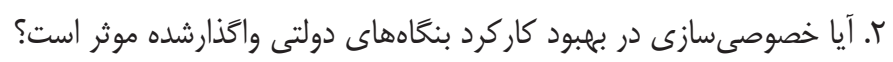

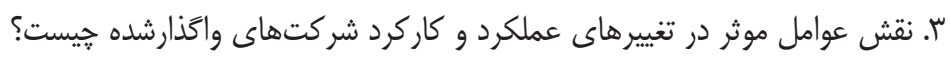


نوع و روش اين يزوهش كمّى، ميدانى، توصيفى، و كاربردى است. جامعه آمارى شامل بنحاههاى

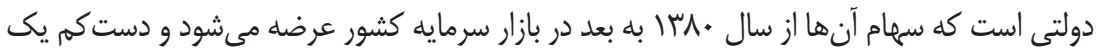

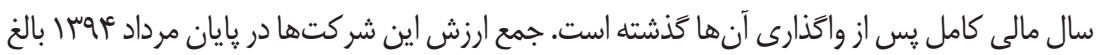

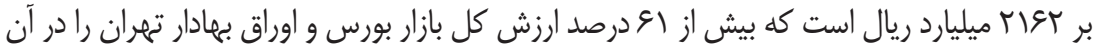

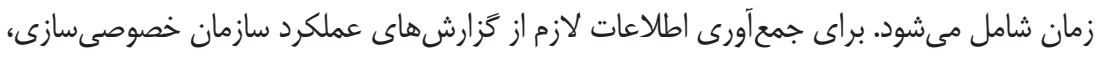
اعلاميههاى يذيرش و عرضه در سوابق سازمان بورس و اوراق بهادار تهران، كزارشهاى عرضه اوليه، صورتهاى مالى سود و زيان، ترازنامه و صورت جريان وجوه نقد منتشرشده و حسابرسى شانده شركتها استفاده مىشود. به منظور حذف آثار تورم و اثر قيمت اسمى، پِ از محاسبه مقان مقادير شاخصهاى اسمى، در همه محاسبهها از دادههاى تعديلشده بر مبناى سرى زمانى شاخص قيمت التان

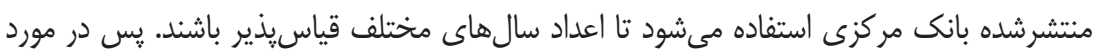
شاخصهاى عملكرد و كاركرد، دو مقدار اسمى و حقيقى محاسبه مىشوند. مقادير عوامل مداخلهَّر

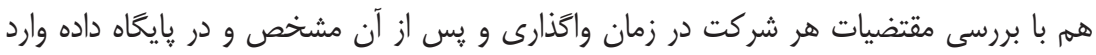

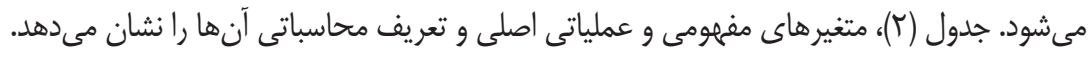

جدول ب: تعريف مفهومى، عملياتى، و محاسباتى متغيرهاى اصلى

\begin{tabular}{|c|c|c|c|c|}
\hline نما & تعريف محاسب & مليا & 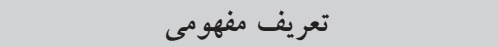 & \\
\hline$\pi_{i t}$ & خالص سود (زيان) & شركت به قيمت سالانه ثابت & 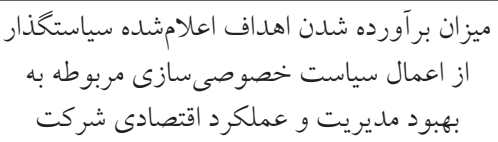 & لكرد \\
\hline $\mathrm{k}_{\mathrm{it}}$ & وجوه نالص جريان & 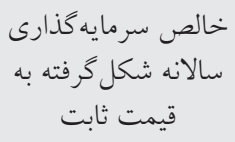 & 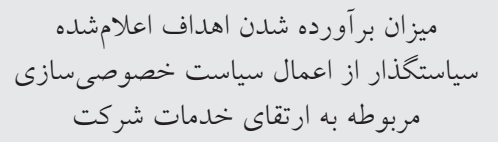 & هردمد \\
\hline
\end{tabular}

براى حذف نوسانهاى غيرمعمول در برخى سالها، براى هر بنغاه سه سال قبل و سه سال

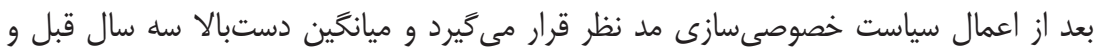
بعد به عنوان متغيرهاى مورد بررسى محاسبه مى شود. اين دو سرى داده براى بررسى تغييرهاى

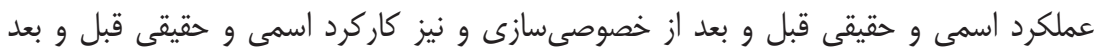

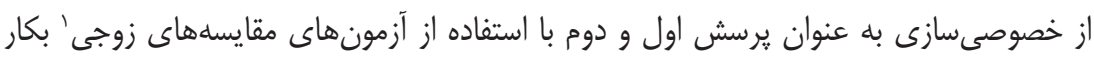

1. Paired Samples Test 
كر فته مىشود. با توجه به ماهيت مقايسهاى و تعداد اعضاى نمونه آمارى، آزمون مقايسههاى زوجى

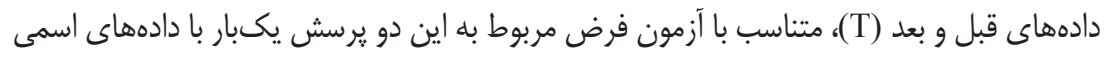
و بار ديخر با دادهاى حقيقى اجرا مىشود.

عوامل مداخلهً راحتمالى بر تاثير خصوصى سازى بر عملكرد و كاركرد شركتها از ادبيات و تجارب

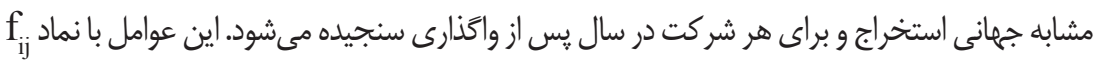

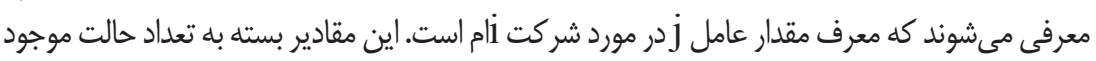

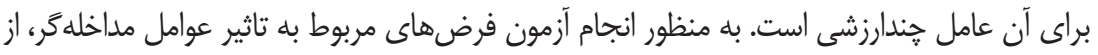
شاخص تغيير مقادير حقيقى دادهاى قبل و بعد عملكرد و كاركرد با فرمول (ا) و ( (ا) استفاده مى شيود. $\bar{\pi}_{\mathrm{i}}=\left(\bar{\pi}_{\mathrm{ia}}-\bar{\pi}_{\mathrm{ib}}\right) / \mathrm{abc}\left(\bar{\pi}_{\mathrm{ib}}\right)$

$\bar{k}_{\mathrm{i}}=\left(\mathrm{K}_{\mathrm{i} a}-\mathrm{K}_{\mathrm{ib}}\right) / \mathrm{abc}\left(\mathrm{K}_{\mathrm{ib}}\right)$

جدول (ץ)، متغيرهاى محاسبهشده مورد استفاده در يزوهش را به اختصار نشان مىدهد.

جدول "ّ: نماد متغير هاى مورد استفاده در ثئوهش

\begin{tabular}{|c|c|}
\hline نماد متغيرها & نمادها \\
\hline مقدار عملكرد بنگاه i در سال t & $\pi_{\mathrm{it}}$ \\
\hline ميانكين عملكرد بنخاه i بعد از خصوصى سازى & $\bar{\pi}_{\mathrm{ia}}$ \\
\hline ميانكين عملكرد بنگاه i قبل از خصوصى سازى & $\bar{\pi}_{\mathrm{ib}}$ \\
\hline شاخص تغييرهاى عملكرد بنكاه i در اثر خصوصى سازى & $\bar{\pi}_{\mathrm{i}}$ \\
\hline مقدار كاركرد بنغاه i در سال t & $\mathbf{k}_{\mathrm{it}}$ \\
\hline ميانكين كاركرد بنغاه i بعد از خصوصىسازى & $\mathrm{k}_{\mathrm{ia}}$ \\
\hline ميانكين كاركرد بنغاه أ قبل از خصوصى سازى & $\overline{\mathrm{K}}_{\mathrm{ib}}$ \\
\hline شاخص تغييرهاى كاركرد بنكاه i در اثر خصوصى سازى & $\mathrm{k}_{\mathrm{i}}$ \\
\hline مقدار عامل مداخلهكر ز در مورد شركت أم & $\mathrm{f}_{\mathrm{ij}}$ \\
\hline
\end{tabular}

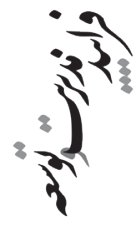

براى انجام آزمون فرضهاى متناظر با اثر عوامل مداخلهَّر با توجه به تعداد بلوكهاى شكلَرفته

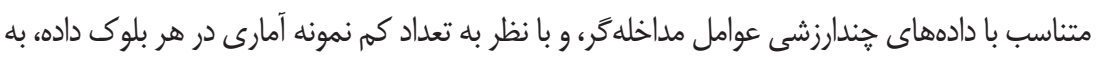

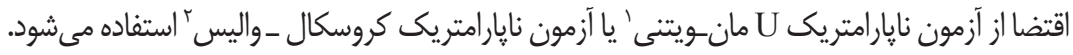

1. U Mann-Whitney

2. Kruskal-Wallis 


\section{تجزيهوتحليل يافتهها}

به دليل اهميت بازشناسى دخالت تمايز دادهاى اسمى و حقيقى، برسشهاى يزوهشى در

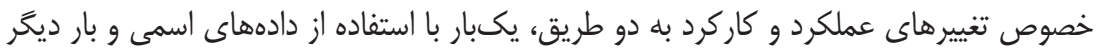

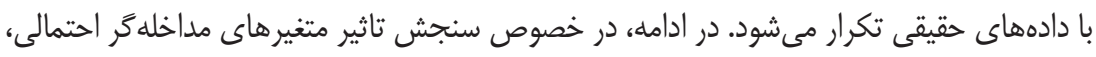

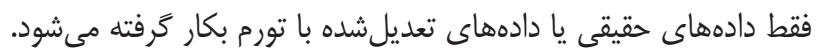

\section{بررسى عملكرد اسمى و حقيقى قبل و بعد از خصوصىسازى}

به منظور بررسى عملكرد اسمى و حقيقى قبل و بعد از خصوصىسازى، آزمون مقايسههاى

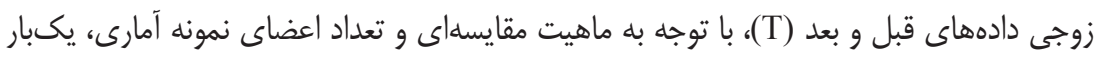

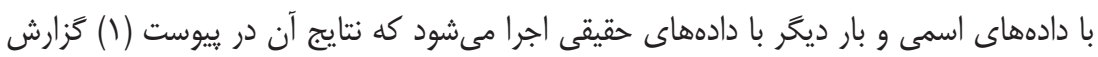

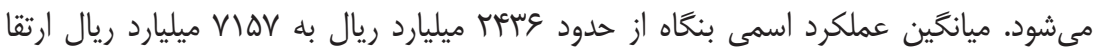

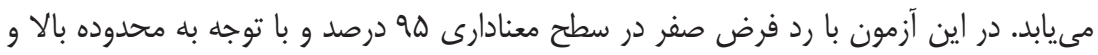

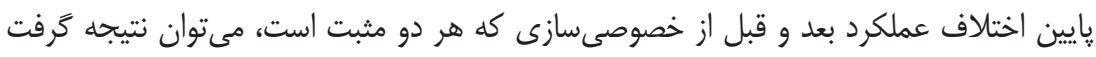

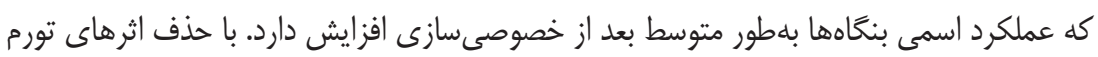

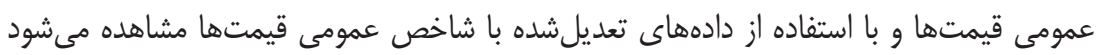

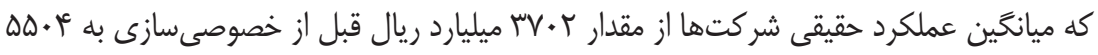

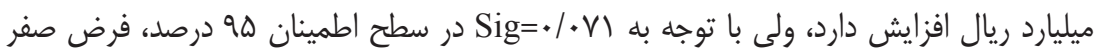

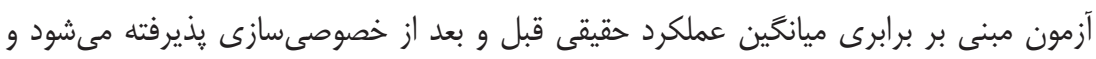

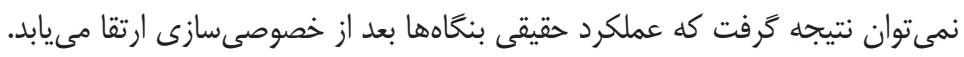

\section{كار كرد اسمى و حقيقى قبل و بعد از خصوصىسازى}

به منظور بررسى كاركرد اسمى و حقيقى قبل و بعد از خصوصىسازى، آزمون مقايسههاى

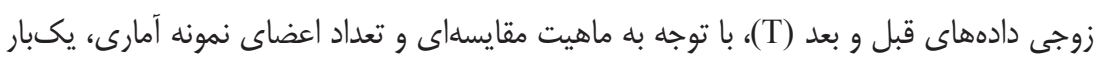

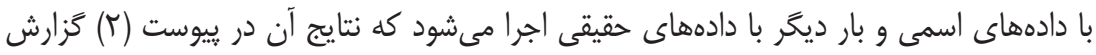

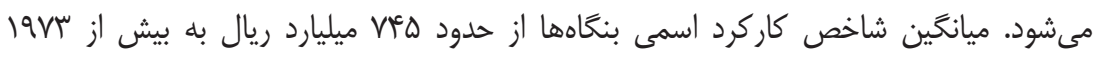

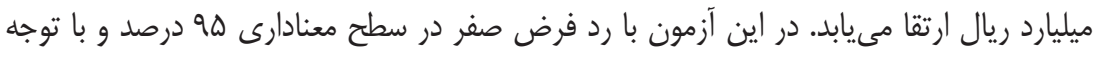

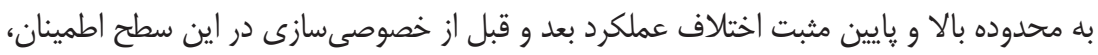

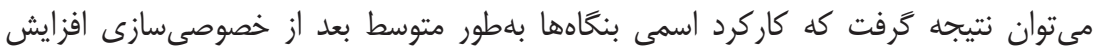


دارد. با حذف اثرهاى تورم عمومى قيمتها و با استفاده از دادهاى تعديلشده با شاخص عمومى

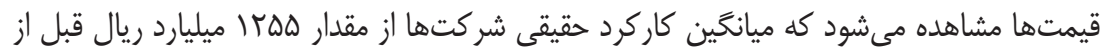

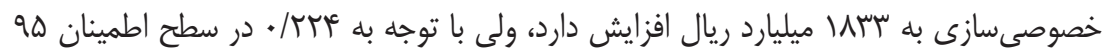

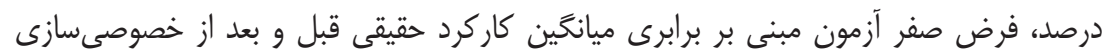

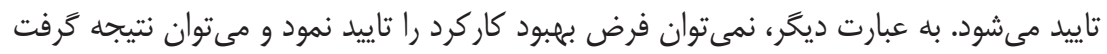
كه تغيير معنادارى در كاركرد حقيقى بنكاهها بعد از خصوصى سازى صورت نعار نغرفته است.

\section{اثر عوامل مداخلهَّر در رابطه خصوصىسازى بر كاركرد و عملكرد بنگَاهها} جدول (أ)، نتايج آزمون فرضهاى متناظر را با يرسش هاى يزوهش مربوط به تاثير هر كدام از عوامل بر رابطه خصوصىسازى بر عملكرد و كاركرد شركتها نشان مىدهد.

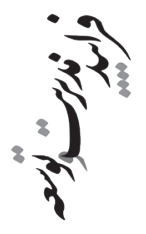

جدول †: خلاصه نتيجه تاثير عوامل مختلف بر رابطه خصوصىسازى بر عملكرد و كار كرد حقيقى شركتها

\begin{tabular}{|c|c|c|c|c|c|c|}
\hline 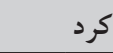 & كار & & عملكرد & T. & ت تعداد & \\
\hline 190\% نتيجه & معنادارى: & نتيجه & معنادارى: 90\% & ازمون & بلوكها & عوامل موتر \\
\hline- & $\cdot 194 \wedge$ & - & $\cdot / 0<q$ & U مانـو يتنى U & r & نهاد واكذارنده \\
\hline- & - TKS & + & $.1 \cdot 49$ & U مانـو يتنى U & r & شكل گيرى حاكميت شركتى \\
\hline- & $\cdot / \wedge$. & + & $\cdot / \cdot{ }^{\prime} \Lambda$ & كروسكال_ـو اليس & $r$ & ماهيت سهامدار غالب \\
\hline- & . /4q4 & - & $\cdot / 9 \cdot 0$ & U مان_و يتنى U & r & برون كرايى \\
\hline- & • NRL & + & $\cdot / \cdot 1 \mathrm{~V}$ & U مان_و يتنى U & r & كتترل مديريت \\
\hline- & $\cdot /$ cru & - & $\cdot / 9 r$. & كروسكالـو اليس & v & ماهيت صنعت \\
\hline- & $\cdot / 901$ & - & $\cdot / 4 N$ & كروسكال_و اليس & 1. & رشته فعاليت صنعتى و حوزه \\
\hline- & $\cdot / 4 \wedge \varphi$ & - & $\cdot 19 \cdot 9$ & كروسكالـو اليس & r & ساختار بازار \\
\hline- & $\cdot / \wedge \cdots$ & - & - NTS & كروسكالــواليس & $r$ & دوره واكذارى \\
\hline- &.$/ 91$ & - & $\cdot / A V^{2}$ & كروسكال_و اليس & r & الزامهاى فرايند خصوصى سازى \\
\hline
\end{tabular}

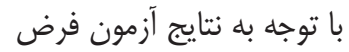


ها، تاييد مىشود كه شكل گيرى حاكميت شركتى، ماهيت سهامدار غالب، و نوع كنترل

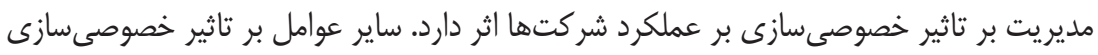

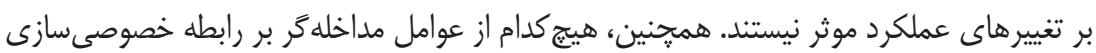
بر كاركرد بنكاههاى عرضهشده اثركذار نيستند.

هدف رسمى اعلامشده خصوصىسازى، جنانجٍه در متن سياست رسمى تشريح مىشود و

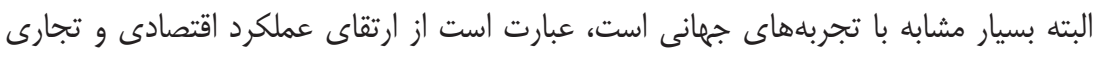

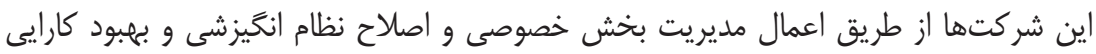

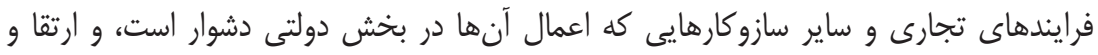

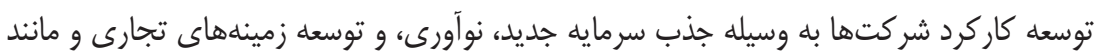

بر مبناى يافتههاى يزوهش مىتوان يذيرفت كه خصوصىسازى بنغاههايى كه ذيل سياست

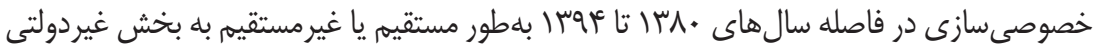

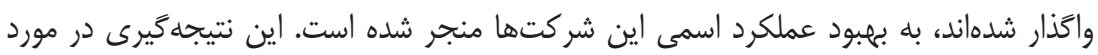

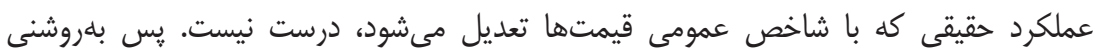

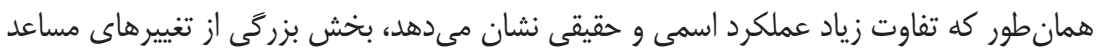

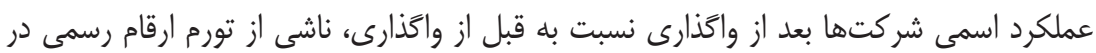

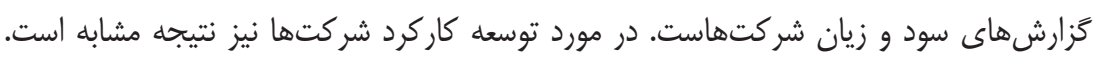

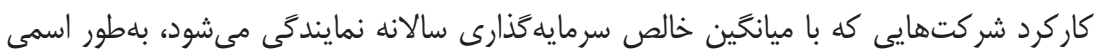

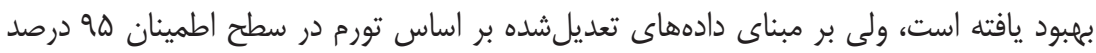

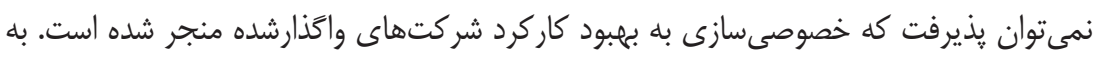

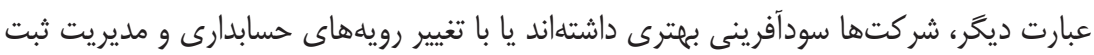

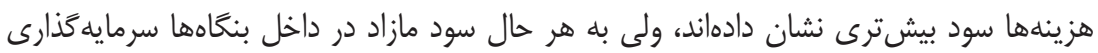

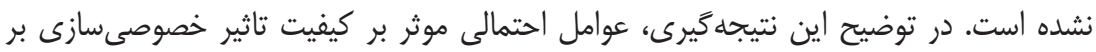

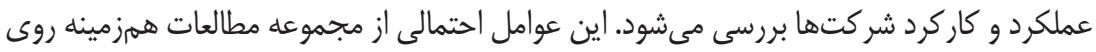

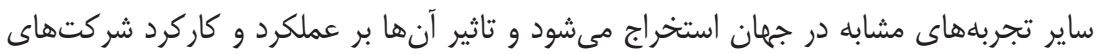

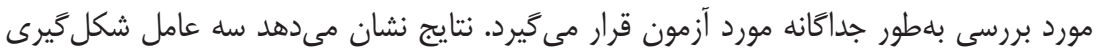


حاكميت شركتى، ماهيت سهامدار غالب، و نوع كنترل مديريتى بعد از انتقال مالكيت، در رابطه

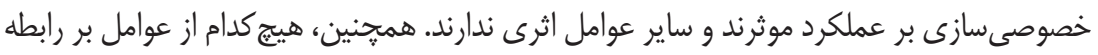
خصوصىسازى بر كاركرد شر كتها موثر نيستند.

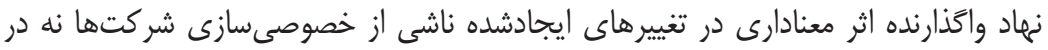

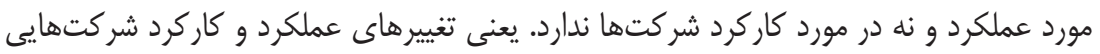
كه بهطور مستقيم توسط دولت عرضه مىشوند، مشابه تغييرهاى شركتهايى است كه توسط شر كتهاى خصوصى شده ييشين عرضه مىشوند. اين نتيجه رجحان واكذارى هولدينكى شر كتها

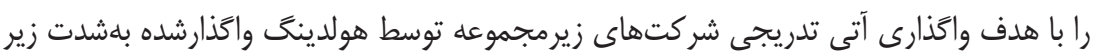

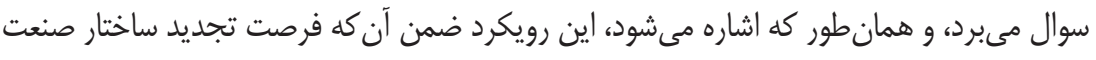

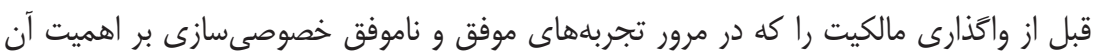
تاكيد فراوان مىشود، از دولت مى گيرد، امكان بهترى براى تخليه سود بنكاهها و ينهان كردن

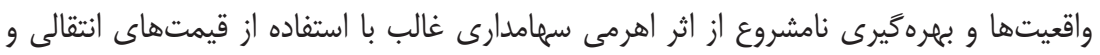

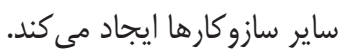
شكل گيرى حاكميت شركتى بر تغييرهاى عملكرد ناشى از خصوصى إسازى موثر است.

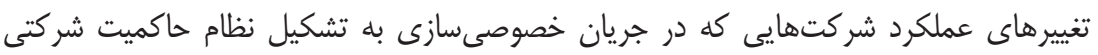
موفق مىشوند، مساعدتر از بقيه شركتهاست. ولى خصوصىسازى به ايجاد حاكميت شركتى دانى

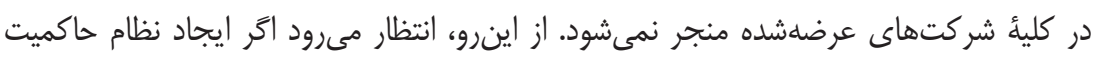
شركتى در دستور كار اجراى سياست خصوصى باشد، نتايج بهترى در خصوص ارتقاى عملكرد

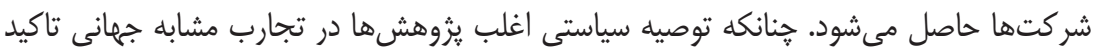

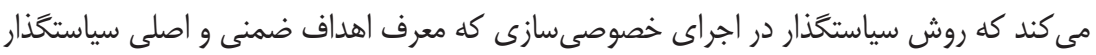
است، موثرتر و تعيين كنندهر از اهداف رسمى اعلامشده است. در مورد توسعه كاركرد شركت، حتى شكل گيرى حاكميت شركتى مشابه با ساير عوامل اثر

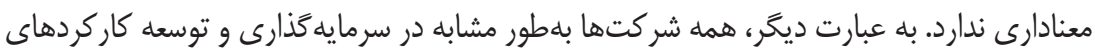
تجارىشان دهار وقفه و شكست هستند و خصوصىسازى تغيير مثبتى در اين خصوص ايجاد نمى كند. ماهيت سهامدار غالب، در اثر خصوصىسازى بر عملكرد بنحاهها موثر است. با توجها

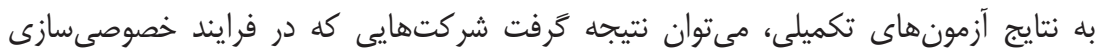

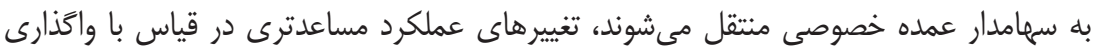

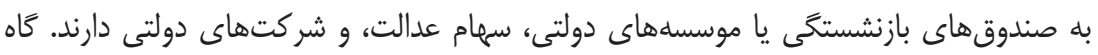


مشاهده مىشود بنيادها و نهادهاى انقلابى و نظامى پس از تملك بخش عمده سهام شركتهاى

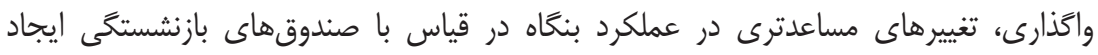

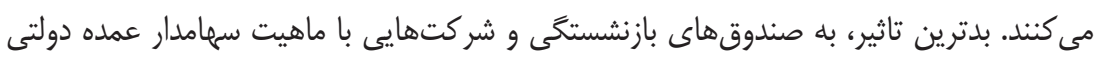

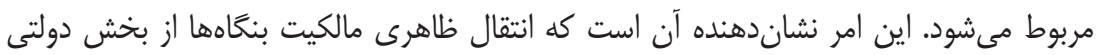

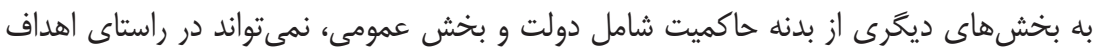

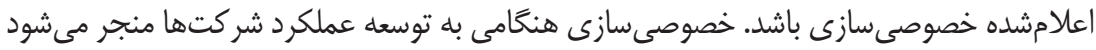

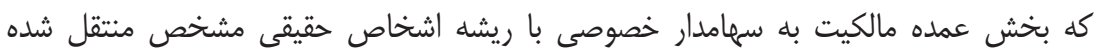

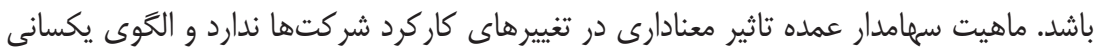

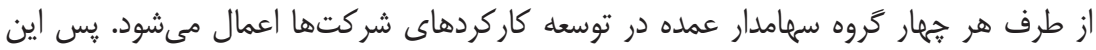

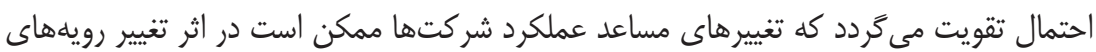
حسابدارى، تقسيه سود بيشتر از واقعيت از شركتهاى زيرمجموعه يا استفاده ابزارى از قيمتهاى انتقالى براى سودسازى بيشتر در كوتاهمدت باشد.

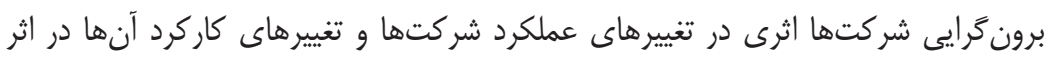

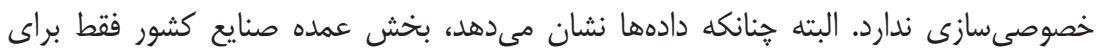

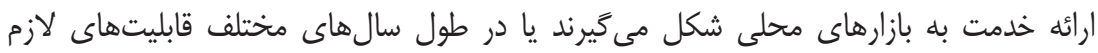
را براى حضور در بازارهاى جهانى ندارند. به عبارت ديگر، شركتهايى با قابليتهاى صادراتى

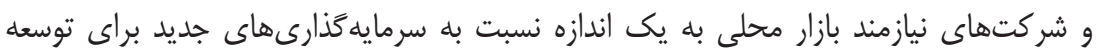

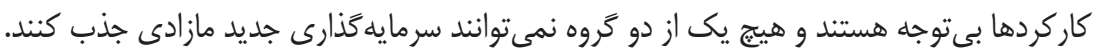

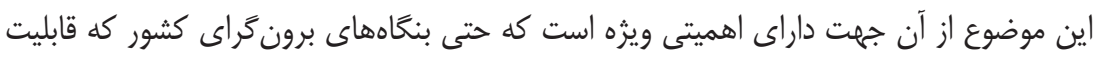

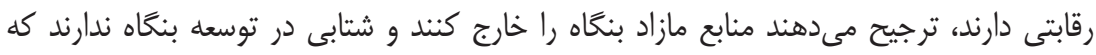

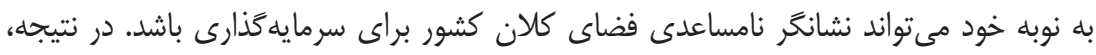

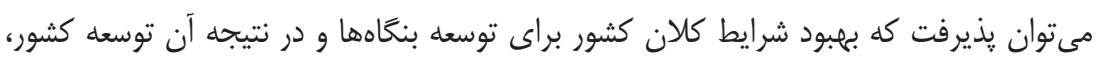
مهمتر از خصوصىسازى يا ماهيت سهامداران شركتهاست.

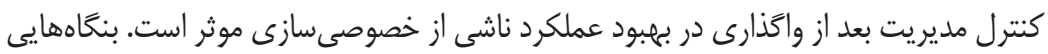
كه يس از خصوصى سازى با سازوكار غيردولتى كنترل مىشوند، تغييرهاى عملكردى مساعدترى

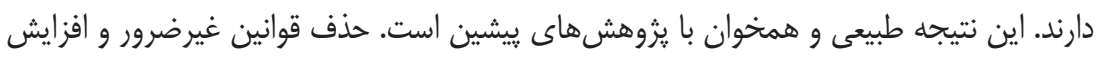

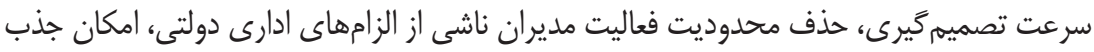

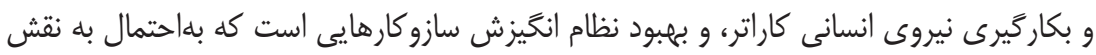


مساعد كنترل غيردولتى در بهبود عملكرد منجر مى شود. اما حتى نوع كنترل دولتى و غيردولتى نيز در تاثير خصوصىسازى بر توسعه كاركرد بنغاهها بـى بـاثر است.

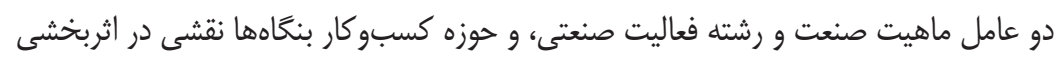

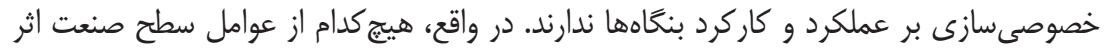

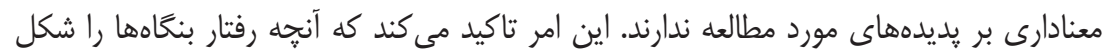
مىدهد، بلطور همخن بر همه حوزهها موثر است و در سطح بالاترى از سلسلهمراتب سياستى قرار

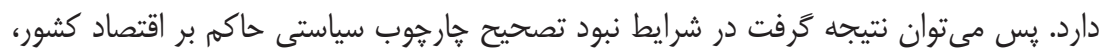
جستجو يا تاكيد بر مزيتهاى نسبى طبيعى يا ايجادشده براى تحريك توسعه بنخاهها جندان موثر

ساختار بازار در تغييرهاى عملكرد و كاركرد بنغاهها قبل و بعد از خصوصىسازى تاثير ندارد. يعنى انحصارهاى ايجادشده و حمايتهاى مقرراتى در برابر رقابت خارجى به مساعدتر شدن

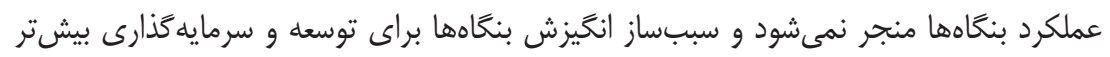

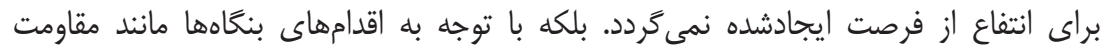

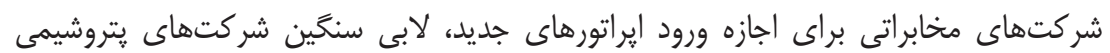

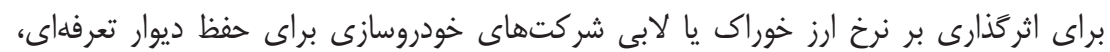

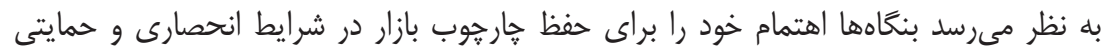

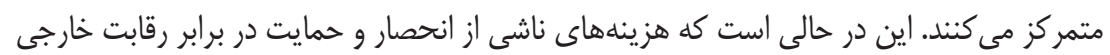

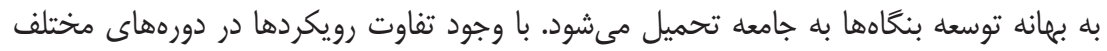

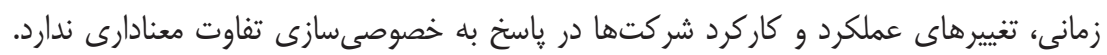

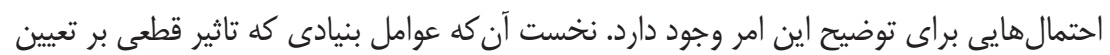

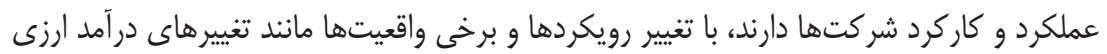

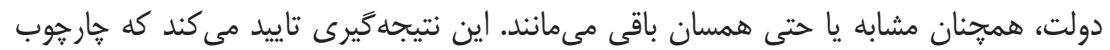
سياستى حاكم و تعيين كننده رفتار آحاد اقتصادى در طول سالهاى مافى مختلف تغيير معنادارى ندارد و همجنان در جهت توسعه بنغاهها نيست. احتمال ديخرى كه وجود دارد، تغيير رويكردها هميشه

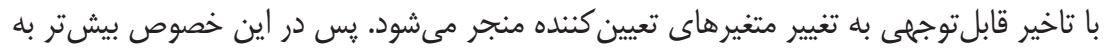

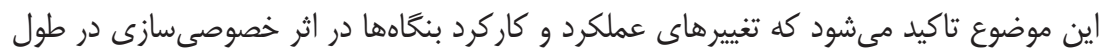
سالها و دورههاى مختلف الخوى مشابهى دارد كه بهاحتمال متاثر از رويكردهاى بنيادى، كيفيتى از خارجوب نهادى موثر بر فعاليتهاى اقتصادى، و اقدامهايى در عمل است كه در طول دور ههاى 
مختلف تقريباً مشابه است و هندان منطبق بر آموزههاى ناشى از تجارب موفق نيست.

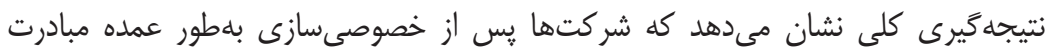

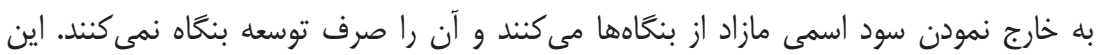
احتمال با توجه به فروش قسطى بنكاهها به نهادهايى كه درجه بالايى از اهرم مالى را براى خرائ خريد

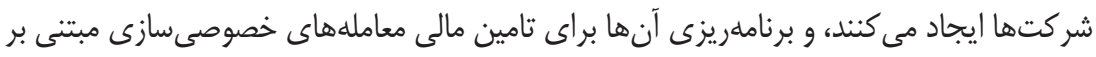

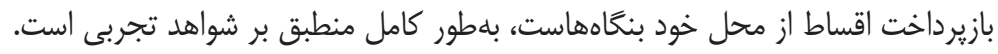

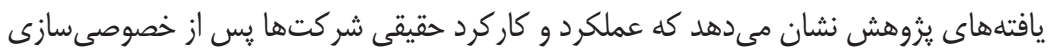

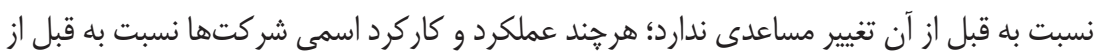
واكذارى بهتر است. در تغييرهاى عملكرد حقيقى بنخاهها فقط عوامل سهامدار غالب، نوع كنترل، و

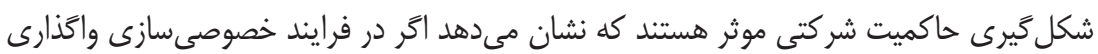
به بخش خصوصى با ريشه اشخاص حقيقى، شكل گيرى حاكميت شركتى هنى و انتقال واقعى كنترل

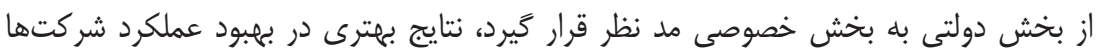
بلبدست مى آيد. در شرايطى از اقتصاد كشور كه بخش خصوصى با ريشه كَرفتن از اشخاص حقيقى، فاقد توان

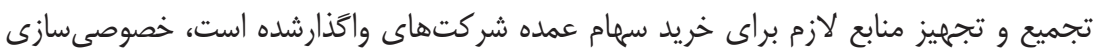

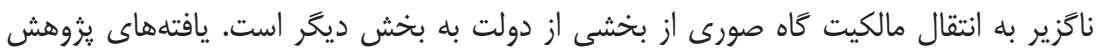

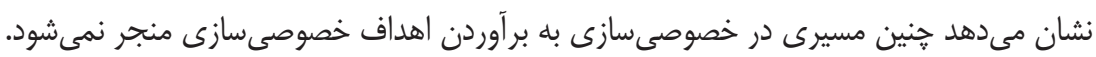

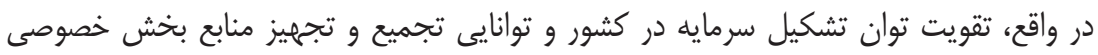

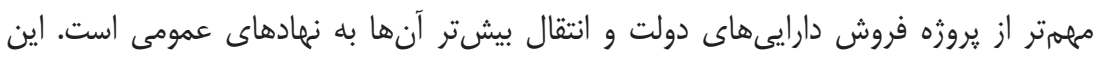

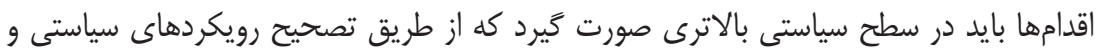

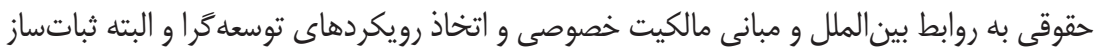

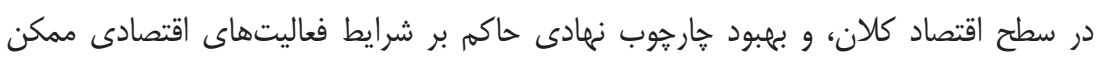

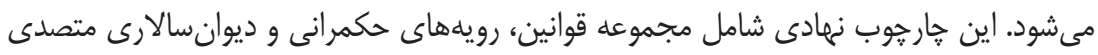

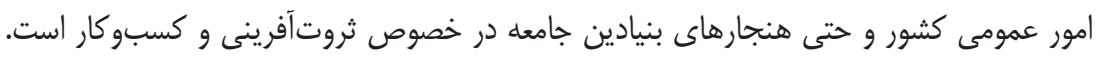

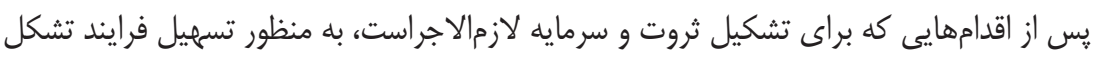

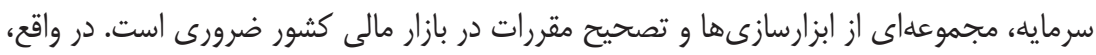

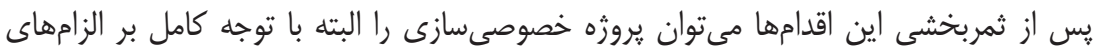

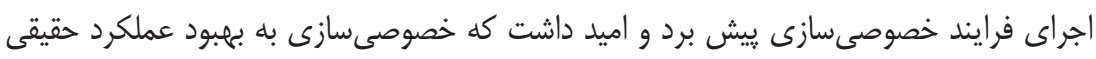




\section{منابع}

\section{الف) فارسى}

اعزازى، محمد اسماعيل؛ فرخى استاد، مجتبى، و فرخى استاد، مصطفى (•وسا). بررسى نقش واگذارى

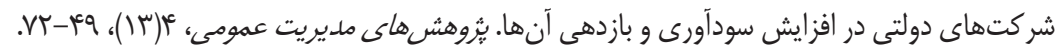

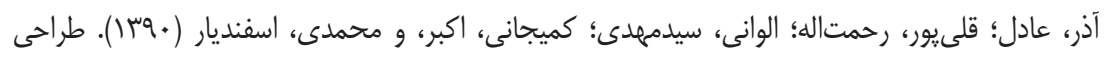

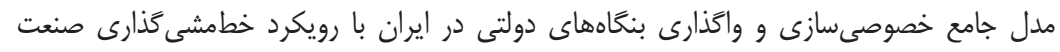

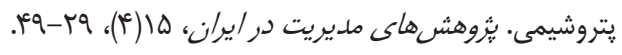

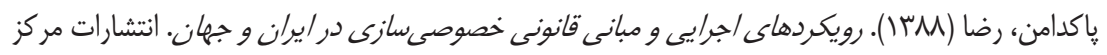
آموزش و تحقيقات صنعتى ايران.

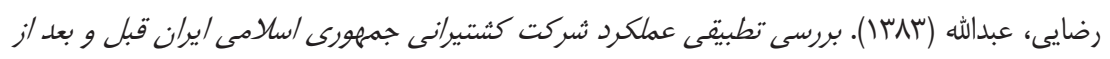

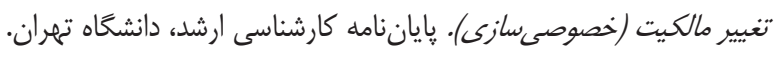

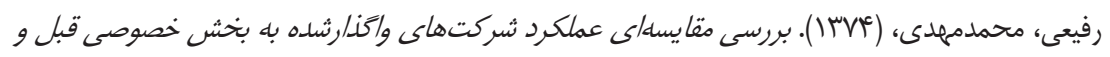

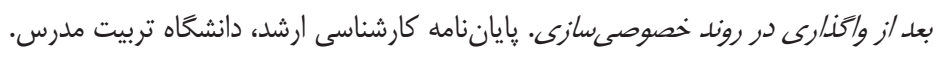

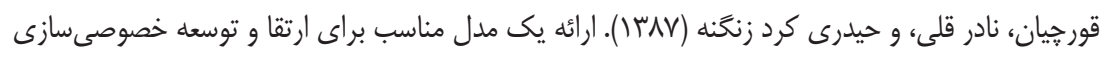

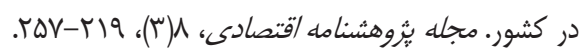

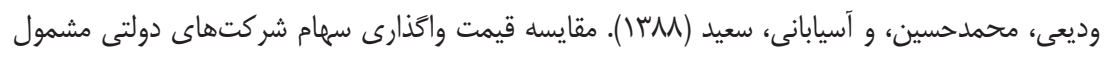

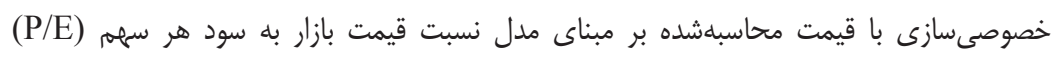

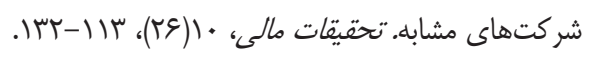

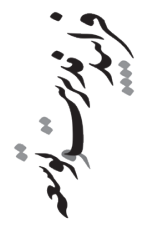


Firms: An Empirical Analysis of Profitability, Leverage, and Labor Intensity. American Economic Review, 91(1), 320-334.

D'souza, J., \& Megginson, W. L. (1999). The Financial and Operating Performance of Privatized Firms during the 1990s. The Journal of Finance, 54(4), 13971438.

Frydman, R., Gray, C., Hessel, M., \& Rapaczynski, A. (1999). When Does Privatization Work? The Impact of Private Ownership on Corporate Performance in the Transition Economies. The Quarterly Journal of Economics, 114(4), 1153-1191.

Macquieira, C., \& Zurita, S. (1996). Privatizaciones en Chile: Eficiencia y politicas financieras. Estudios de Administracion, 3(2), 1-36.

Majumdar, S. K. (1998). Assessing Comparative Efficiency of the State-Owned Mixed and Private Sectors in Indian Industry. Public Choice, 96(1-2), 1-24.

Megginson, W. L., Nash, R. C., \& Van Randenborgh, M. (1994). The Financial and Operating Performance of Newly Privatized Firms: An International Empirical Analysis. The Journal of Finance, 49(2), 403-452.

Parker, D. (1997). Price Cap Regulation, Profitability and Returns to Investors in the UK Regulated Industries. Utilities Policy, 6(4), 303-315.

Petrazzini, B. A., \& Clark, T. H. (1996). Costs and Benefits of Telecommunications Liberalization in Developing Countries. Institute for International Economics, Washington, DC.

Pinto, B., Belka, M., Krajewski, S., \& Shleifer, A. (1993). Transforming State Enterprises in Poland: Evidence on Adjustment by Manufacturing Firms. Brookings Papers on Economic Activity, 1993(1), 213-270.

Tian, G. L. (2000). State Shareholding and Corporate Performance: A Study of a Unique Chinese Data Set. Working Paper, London Business School.

Verbrugge, J. A., Megginson, W. L., \& Lee, W. (1998). The Financial Performance of Privatized Banks: An Empirical Analysis, Working Paper: University of Georgia.

Verbrugge, J., Owens, W., \& Megginson, W. (1999). State Ownership and the Financial Performance of Privatized Banks: An Empirical Analysis. Paper Presented at the Conference Proceedings of a Policy Research Workshop Held At the World Bank. 


\section{ييوست}

جدول إ: نتيجه آزمون بررسى عملكرد اسمى و حقيقى قبل و بعد از خصوصىسازى

الف: آمار نمونه زوجى

$\begin{array}{llll}\text { Mean } & \text { N Std. Deviation } & \text { Std. Error Mean }\end{array}$

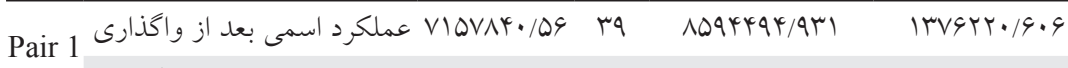

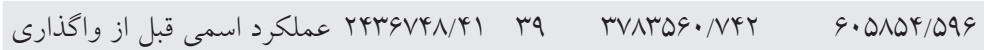

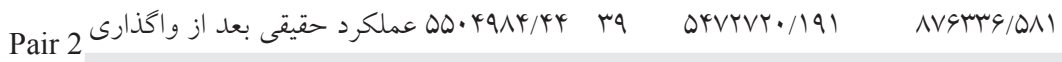

r عملكرد حقيقى قبل ازواگذارى

ب: نتايج آزمون مقايسههاى زوجى

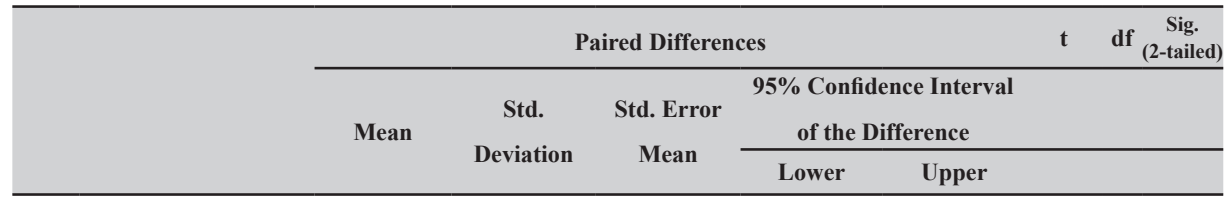

عملكرد اسمى بعد از

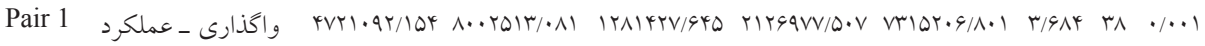

اسمى قبل از واكذارى

عملكرد حقيقى بعل

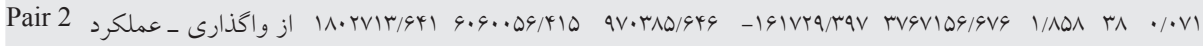
حقيقى قبل از واكذارى 
بيوست ب

جدول זّي: نتيجه آزمون بررسى كاركرد اسمى و حقيقى قبل و بعد از خصوصىسازى الف: آمار نمونه زوجى اسمى

$\begin{array}{llll}\text { Mean } & \text { N Std. Deviation Std. Error Mean }\end{array}$

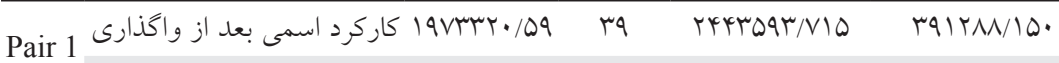
r Vاركرد اسمى قبل از واكذارى

Pair ه هب

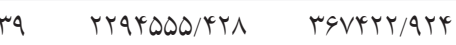

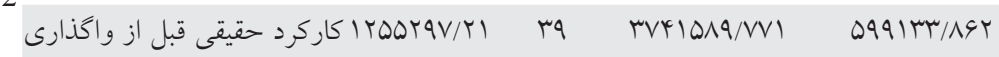

\begin{tabular}{|c|c|c|c|c|c|c|c|c|}
\hline & \multicolumn{5}{|c|}{ Paired Differences } & \multirow[t]{3}{*}{$\mathbf{t}$} & \multirow{3}{*}{\multicolumn{2}{|c|}{ If $\begin{array}{c}\text { Sig. } \\
(2 \text {-tailed })\end{array}$}} \\
\hline & \multirow[t]{2}{*}{ Mean } & \multirow[t]{2}{*}{$\begin{array}{c}\text { Std. } \\
\text { Deviation } \\
\end{array}$} & \multirow[t]{2}{*}{$\begin{array}{c}\text { Std. Error } \\
\text { Mean } \\
\end{array}$} & \multicolumn{2}{|c|}{$\begin{array}{c}5 \% \text { Confidence Interval } \\
\text { of the Difference }\end{array}$} & & & \\
\hline & & & & Lower & Upper & & & \\
\hline 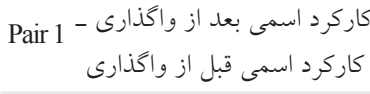 & ITYMYYT/AVT & IVGGT. T/FVQ & TATAINNEY & $90 \cdot M 49 / 491$ & IVQDQDQ/ศAr & F/TYG & $\mu_{\Lambda}$ & $\cdot \cdots$ \\
\hline 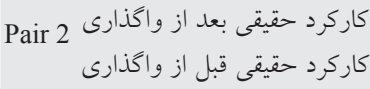 & $\Delta V \wedge \cdot V 9 / \wedge r I$ & rq19T.0/99T & KEVYKV/.94 & - & DOTKTVG/ATT & $1 / T r V$ & rs & DTrY \\
\hline
\end{tabular}

